\title{
ENVIRONMENTAL IMPACT ASSESSMENT, PERSONAL HYGIENE, AND OCCUPATIONAL HISTORY ON THE INCIDENCE OF DERMATITIS
}

\author{
Marniati $^{1^{*}, \text { Enda Silvia Putri², Sufyan Anwar }}{ }^{3}$, Itza Muliyani ${ }^{4}$, Susy Sriwahyuni $^{5}$, \\ Khairunnas ${ }^{5}$
}

\author{
Faculty of Public Health, Teuku Umar University, Aceh Barat, Aceh, Indonesia. \\ email:marniati@utu.ac.id
}

\begin{abstract}
The environment is a very influential factor in the incidence of dermatitis. Dermatitis is a skin disease that is acute, sub-acutel or chronic caused by inflammation of the skin that occurs due to exogenous and endogenous factors. The problem in this study is the high prevalence of dermatitis in the community, reaching 623 cases. The purpose of this study is to analyze the analysis of the impact of environmental studies, personal hygiene, and work history on the incidence of dermatitis in the community in the Darul prosperous sub-district, Nagan Raya district. This research method is an analytic design with a Cross-sectional design. This research was carried out in December 2020 which became the population of people with Dermatitis with a sample of 86 respondents. This study was analyzed using univariate and bivariate, then tested by Chi-Square test. The results of the study after being tested stated that there was an influence of environment, personal hygiene, and work history on the incidence of dermatitis as evidenced by the P.value 0.05. The conclusion after analyzing the effect of the model on the impact of work history, personal hygiene, and the environment there is an influence on the incidence of dermatitis. Among all these variables the most powerful influence is the environmental variable. Suggestions to the Puskesmas to further improve policies in dealing with the incidence of dermatitis by approaching and empowering the community so that a dermatitis-free society is achieved.
\end{abstract}

Keywords: Dermatitis, Environment, Personal Hygiene, Occupational History.

\section{PRELIMINARY}

Dermatitis is an acute, sub-acute, or chronic skin disease caused by inflammation of the skin. This disease occurs due to exogenous and endogenous factors. Signs of clinical abnormalities in the form of polymorphism and complaints of itching on the skin. There are two types of dermatitis, including contact dermatitis and atopic dermatitis (Emanuel, S., \& Hawarden, D. (2018). Dermatitis is one of the world's public health problems with a prevalence in children of $10-20 \%$ and in adults around 1-3\%. About $50 \%$ of cases of dermatitis appear in the first year of life (Gofur \& Syam, 2018).

Araghi, F., et al, (2020) The incidence of dermatitis in the world is very common where almost all types of dermatitis are associated with regular hand hygiene can also be a challenge, because water, detergents, and disinfectants can influence health workers, not to got hand dermatitis. And this dermatitis can attack anyone and can attack any part of the body (Kong, S., Koo, J., \& Lim, S. K. 2020). And dermatitis is one of the diseases that are often found in tropical countries like Indonesia. The epidemiological importance of chronic 
dermatitis continues to grow, this pathology is becoming more and more common regardless of age, in most countries of the world Rotaru, M., et al, 2020. The authors concluded that many of the infections or other skin conditions such as acne associated with seborrheic dermatitis (Zander, N., et al, 2019) are conditions in which there are microbial changes (small organisms) in the skin (microbiome) and/or production fat or sebum on the surface of the skin.

According to the World Health Organization (WHO) in the 2013 American Academy of Allergy, Asthma, and Immunology (AAAAI) survey, dermatitis is a common skin problem where there are 5.7 million doctor visits per year due to dermatitis. In general, dermatitis is more prone to attack adolescents and adults, but ages above 30 years to middle age tend to improve or recover (Who, 2014). The incidence of dermatitis in Indonesia is still relatively high and is a significant problem. This is due to the lack of awareness and ignorance of the community towards the surrounding environment which causes the transmission of skin diseases (dermatitis) very quickly. Some dermatitis can be caused by several factors such as the environment and bad daily habits, climate change, viruses, bacteria, allergies, body resistance, and others (Pardiansyah, 2015). The Ministry of Health of the Republic of Indonesia released the development of skin diseases suffered by the Indonesian people in the 2015 Indonesian Health Profile. The report shows that skin diseases occupy the top three positions with the highest number of outpatients in Indonesia. In total, there were 192,414 visits, with 122,076 new case visits and 70,338 old cases (Kemenkes RI, 2016).

In Aceh province in 2017, the incidence of dermatitis reached 53,461 cases, while in Nagan Raya district, cases of dermatitis increased from year to year, wherein in 2017 there were 756 cases, in 2018 there were 967 and in 2019 it increased to 1,247 cases. Among several health centers in Nagan Raya, Alue Rambot Health Center has the highest dermatitis cases, namely In 2017 the number of cases of dermatitis was 278 cases, in 2018 it reached 261 cases, while in 2019 it reached 623 cases of dermatitis. (Alue Rambot Health Center, 2019).

According to (Djafri and Syam 2018) in their research, he explained that personal hygiene, environmental sanitation (clean water facilities), and allergies could affect the incidence of dermatitis in research conducted in the work area of the Rappokalling Health Center. Personal hygiene, namely the cleanliness of towels, body hygiene (bathing), hand and nail hygiene are directly related to the incidence of dermatitis, this is because people who have low education, have low levels of knowledge and awareness to always maintain their personal hygiene. Moreover, they live in densely populated areas and have poor environmental conditions, so that contact with the environment and other people is higher.

Based on the results of a survey conducted with some people with dermatitis, it was stated that it had something to do with their work history, in addition to personal hygiene and an unhygienic environment such as a wet, humid or hot environment. Based on the description of the problem above, it is necessary to conduct research on "Analysis of environmental impact studies, personal hygiene and work history on the incidence of dermatitis.

\section{RESEARCH METHODS}

This type of research is an analytical study with a Cross-Sectional design which was carried out in the Alue Rambot Health Center Work Area, Darul Makmur District, Nagan Raya Regency in December 2020. The population in this study were people with Dermatitis, 


\section{ORFAI JOURNAL Multidiciplinary Output Research For Actual and International Issue}

with a sample of 86 respondents. Data were analyzed using univariate and bivariate, then tested with Chi-square.

\section{RESEARCH RESULT}

Univariate Analysis

Table 1 Distribution of Frequency Based on Occupational History, Personal Hygiene and Environment on the Incidence of Dermatitis

\begin{tabular}{lcc}
\hline $\begin{array}{l}\text { Variables } \\
\text { Job Experiences }\end{array}$ & frequency & $\%$ \\
Housewife & 32 & 37,2 \\
Farmer & 54 & 62,8 \\
Personal Hygiene & & \\
Good & 36 & 41.9 \\
Not good & 50 & 58.1 \\
Environment & & \\
Good & 32 & 37,2 \\
Not good & 54 & 62,8 \\
Occurrence of Dermatitis & & \\
Long & 32 & 37,2 \\
New & 54 & 62,8 \\
\hline
\end{tabular}

from the results of the univariate analysis above, it is known that from 86 respondents there are $(62.8 \%)$ respondents who have a history of working as farmers while $32(37.2 \%)$ respondents who work as housewives. According to the results of the analysis above, it is known that from 86 respondents there were $50(58.1 \%)$ respondents whose personal hygiene was not good, while $36(41.9 \%)$ of respondents had good personal hygiene. After being analyzed, it was found out that from 86 respondents, $54(62.8 \%)$ respondents had a bad environment, while 32 (37.2\%) respondents had a good environment. According to the results of the analysis obtained, it is known that from 86 respondents, 54 respondents $(62.8 \%)$, who experienced the incidence of new dermatitis were 32 respondents $(37.2 \% \%)$.

\section{Bivariate Analysis}

Table 2 Analysis of the impact of work history on the incidence of dermatitis

\begin{tabular}{lcccccccc}
\hline Job Experiences & Long & \multicolumn{3}{c}{ New } & \multicolumn{1}{c}{ Total } & Value & RP \\
& $\mathrm{f}$ & $\%$ & $\mathrm{f}$ & $\%$ & $\mathrm{f}$ & $\%$ & & \\
housewife & 11 & 34,4 & 21 & 65,6 & 32 & 100 & 0,002 & 2,215 \\
Farmer & 38 & 70,4 & 16 & 29,6 & 54 & 100 & & \\
\hline
\end{tabular}

Based on table 4.5 , it is known that from 54 respondents who work as farmers, 38 respondents $(70.4 \%)$ are old patients who have experienced dermatitis. On the other hand, of the 32 respondents who worked as IRT, 21 respondents $(65.6 \%)$ had experienced dermatitis. According to the statistical test using Chi-square, the P-value $=0.002$ and this is smaller than 0.05 (P.value 0.0020 .05 ) so it can be said that there is an effect of the impact of work history on the incidence of dermatitis.

Table 3 Analysis of the Impact of Personal Hygiene on the incidence of dermatitis 
Volume 1 No 1 (2021)

Environmental Impact Assessment, Personal Hygiene, And Occupational History On The Incidence Of Dermatitis

Marniati, Enda Silvia Putri, Sufyan Anwar, Itza Muliyani, Susy Sriwahyuni, Khairunnas

\begin{tabular}{lcccccccc}
\hline Personal hygiene & Long & \multicolumn{3}{c}{ New } & \multicolumn{1}{c}{ Total } & Value & RP \\
& $\mathrm{f}$ & $\%$ & $\mathrm{f}$ & $\%$ & $\mathrm{f}$ & $\%$ & & \\
Good & 8 & 22,2 & 28 & 77,8 & 36 & 100 & 0.002 & 2,610 \\
Not good & 29 & 58,0 & 21 & 42,0 & 50 & 100 & & \\
\hline
\end{tabular}

Table 3 above shows that of the 50 respondents who had poor personal hygiene and were old sufferers as many as 29 respondents (58.0\%). On the other hand, from 36 respondents, $28(77.8 \%)$ had good personal hygiene and were new sufferers of dermatitis. The results of statistical tests using chi-square obtained $\mathrm{P}$-value $=0.002$ this value is smaller than $=0.05$ (P.value $0.002<0.05$ ) so it can be concluded that there is an effect of personal hygiene on the incidence of dermatitis.

Table 4 Environmental Impact Assessment Analysis on the incidence of Dermatitis

\begin{tabular}{lcccccccc}
\hline Environment & Long & \multicolumn{5}{c}{ New } & \multicolumn{3}{c}{ Total } & Value & RP \\
& $\mathrm{f}$ & $\%$ & $\mathrm{f}$ & $\%$ & $\mathrm{f}$ & $\%$ & & \\
Good & 6 & 18,8 & 26 & 81,2 & 32 & 100 & 0,001 & 3,062 \\
Not good & 31 & 57,4 & 23 & 42,6 & 54 & 100 & & \\
\hline
\end{tabular}

Based on table 4.7 above, it is known that from 54 respondents, there are $31(57.4 \%)$ respondents who suffer from old dermatitis with unfavorable environmental conditions. In contrast, from 32, there were $26(81.2 \%)$ respondents who had new dermatitis with unfavorable environmental conditions. From the statistical test using chi-square, it was found that the $\mathrm{P}$-value $=0.001$ this value is smaller than $=0.05$ (P.value $0.001<0.05$ ) so it can be concluded that there is an environmental impact on the incidence of dermatitis.

\section{DISCUSSION}

\section{Analysis of the impact of Occupational History on the incidence of dermatitis}

The results of statistical tests using chi-square obtained a P-value of 0.002 which means it is smaller than the value of 0.05 ) so it can be concluded that there is an influence of work history on the incidence of dermatitis. From the results of the Prevalence Ratio value with a value of 2.214 , it can be concluded that respondents who have a history of work as farmers will have a 2,214 times chance of suffering from dermatitis compared to respondents who have a history of working as domestic workers.

Occupational history is one of the factors that can be considered as a cause of dermatitis. It is possible that dermatitis suffered due to the type of work he is currently undergoing is more likely to be in direct contact. Some respondents who were detected as suffering from dermatitis had jobs as farmers, salons, printing houses, and others. For example due to exposure to foreign objects, chemicals, biology, or the previous work environment (Suryani, 2011).

According to the observations of researchers in the field, respondents who work as farmers are more likely to suffer from dermatitis, in addition to this type of work-related to direct contact also because respondents work $>8$ hours per day so they are often exposed to dermatitis.

According to research (Melo, M. das G. M., et al, 2019), the possibility of the appearance of dermatitis is caused by a person's work history where work outside the home is more at risk of developing dermatitis. A professional musician has prolonged and intense physical contact with their instruments while working (Kraft, M., et al, 2019) this can cause occupational skin diseases, especially irritant and allergic contact dermatitis. Occupational skin diseases dominate the spectrum of occupational diseases indicating that comprehensive 


\section{ORFAI JOURNAL Multidiciplinary Output Research For Actual and International Issue}

prevention programs positively influence the course of high-risk work-related skin diseases (Wilke, A., et al, 2018)

\section{Analysis of the impact of Personal Hygiene on the incidence of dermatitis}

From the results of statistical tests using the chi-square test, the P-value of 0.002 is obtained, which means it is smaller than 0.05) so that it can be concluded that there is an influence of personal hygiene on the incidence of dermatitis. Based on the results of the Prevalence Ratio with a value of 2.610 , it can be concluded that respondents who have poor personal hygiene will have a chance of 2,610 times suffering from dermatitis and conversely, respondents who have good personal hygiene are most likely not to develop dermatitis.

According to researchers in the field, respondents who have poor personal hygiene are definitely suffering from dermatitis because respondents do not maintain good personal hygiene, respondents do not immediately change dirty clothes used when working, these clothes are still used when coming home from work. Respondents who did not immediately take a clean shower and did not change clothes. Respondents first took a break or did other homework such as washing dishes and sweeping the yard. Personal hygiene of respondents, the researcher assumes that there is a lack of respondents in maintaining personal hygiene, where there are still many respondents who do not immediately change clothes after coming home from work, there are still respondents who use work clothes for a few days that have been used, there are still respondents who do not wash their hands and feet after work so that the condition of wet and dirty feet is likely to quickly develop dermatitis.

On the other hand, respondents who have good personal hygiene and always maintain personal hygiene by immediately changing to work clothes that are already dirty, i.e. immediately taking a clean shower and using clean clothes again. These respondents maintain personal hygiene by using clean clothes when working so that the clothes used when working are always clean and avoid dermatitis.

Personal hygiene is an action to maintain the cleanliness and health of a person for personal hygiene, both physically and psychologically. Personal hygiene is one of the factors that cause dermatitis. Personal hygiene in question is the habit of bathing, washing hands and feet using running water and soap after work, and washing work clothes after returning from work (Rahmatika, 2020).

According to (Bahari, MIY, \& Paramita, DA (2020) dermatitis can occur due to a person's personal hygiene. To maintain or improve personal health by keeping the body and environment clean. Personal hygiene can affect the surrounding environment, one of which is by affecting household hygiene. The results of this study are in line with research (Wati, 2017) Personal hygiene factors turned out to be factors that influence the incidence of dermatitis. Personal Hygiene problems have an impact on the type of work that is in direct contact with human skin, one study found that out of 60 respondents studied there was an influence There is a significant relationship between personal hygiene and the incidence of dermatitis in waste scavengers with a P-value of 0.001 (Dewi, 2016). This is in line with research (Bahari, MIY, \& Paramita, DA (2020).) which states that personal hygiene can affect the surrounding environment, one of which is by affecting the cleanliness of the house stairs, therefore it is necessary to improve cleanliness in the environment around the household.

\section{Environmental impact assessment analysis on the incidence of dermatitis}

Based on the results of statistical tests using chi-square, the P-value of 0.001 was obtained, this value is smaller than $=0.05 /$ so that there is an influence of environmental 
impacts on the incidence of dermatitis. more times suffer from dermatitis than respondents whose environment is good.

According to the observations of researchers in the field, where the researchers found that respondents who had a clean environment had fewer cases of dermatitis because they kept their environment clean of their body parts, clothes, houses, and the environment around their homes so that germs did not stick around them and avoided the incidence of dermatitis. Furthermore, respondents who have an unsanitary environment are more likely to experience dermatitis because they do not keep their environment clean from their body parts, clothes, houses, and the environment around their homes so that it can cause germs to be around them and experience dermatitis. The environment is a factor that triggers or aggravates dermatitis. And an unfavorable environment has a risk of dermatitis. For example, a dusty, dry, or humid environment in the absence of sunlight will be a medium for the development of bacteria or fungi, this is in accordance with the theory explained by (Utama, 2014).

The results of the research above are supported by the results of Anwar's research (2016) at the Bakinang Health Center where there is a relationship between the environment and the incidence of dermatitis. Furthermore, the results of this study are also supported by Fitriani's research (2015), in the Wajo district where there is a relationship between the environment and the incidence of dermatitis with a P-value $=0.000$.

Research (Lovez, et al, 2020) says that a complex disease with host and underlying environmental factors is pathology, which proposes a new step-by-step approach aimed at maintaining disease control and improving quality of life. Disease type exposure caused by the environment with respect to its effect on pathogenesis is an important domain that can cause exacerbation or improvement of diseases (Stefanovic, Net al, 2021) such as climate change, migration, and urbanization, such as air pollution, water hardness, and allergic sensitization, individual factors such as diet, changes in the microbiome, psychosocial stress and the impact of topical and systemic therapies.

\section{CONCLUSION}

Analysis Environmental impact studies are closely related to the incidence of dermatitis, which is then followed by work history and personal hygiene. The impact on the environment affects several aspects, namely water conditions that are not standard from a physical point of view, namely color, smell, and taste. Furthermore, in terms of humidity and room temperature are also not good so this increases the number of cases of dermatitis in this area.

\section{SUGGESTION}

In its implementation, the Puskesmas should further improve policies on dealing with the incidence of dermatitis by improving the environment in terms of water, temperature, and air. Furthermore, community personal hygiene assistance and community work history to achieve a dermatitis-free community as expected.

\section{REFERENCES}

Araghi, F., Tabary, M., Gheisari, M., Abdollahimajd, F., \& Dadkhahfar, S. (2020, July 1). Hand Hygiene among Health Care Workers during COVID-19 Pandemic: Challenges and Recommendations. Dermatitis. Lippincott Williams and Wilkins. https://doi.org/10.1097/DER.0000000000000639 


\section{ORFAI JOURNAL Multidiciplinary Output Research For Actual and International Issue}

Emanuel, S., \& Hawarden, D. (2018). Dermatitis. Current Allergy and Clinical Immunology, 31(3), 164-165. https://doi.org/10.29309/tpmj/2018.25.06.268

Gofur, A., \& Syam, N. 2018.Determinan Kejadian Dermatitis Di Puskesmas Rappokaling Kota Makassar.Jurnal Keseahata Masyarakat ,E-ISSN 2614-5375. Depkes RI,Riset Kesehatan Dasar, Jakarta, 2017.

Lestari, F., Utomo, H. .2017. Faktor- Faktor yang Berhubungan dengan Dermatitis Kontak pada.Pekerja di PT Inti Pantja PressIndustri.Makara Kesehatan,11(2): 61-70.

Marniati, M., Putri, E. S., Sriwahyuni, S., hairunnas, K., \&Duana, M. (2020). Knowledge Study, Income Level and Socio-Culture of the Nutritional Status of a toddler. Journal of Nutrition Science, 1(2), 38-44.

Marniati, M. (2016, December). The Influence of People's Knowledge and Attitudes Toward Traditional Treatment. In 1st Public Health InternationalConference (PHICo 2016) (pp. 159-162). Atlantis. Press

Kemenkes RI.(2016).Profil Kesehatan Indonesia. Jakarta : Kementrian republik Indonesia.

Kemenkes RI. 2018. Profil kesehatan Indonsia 2017. Jakarta : Kemenkes RI.

World Health Organization (2017). Mental Disorders fact sheets. World Health Organization.

World Health Organization 2014.Ocupational . Contact Dermatitis.Available .atwww. who.int/ gho/data/organisasi kesehatan duniadiaksespada tanggal15 desember 2019.

Profil Dinkes Aceh.2017, Profil kesehatan Aceh 2017. Aceh

Profil Dinkes Nagan Raya. 2019. Profil Kesehatan Nagan Raya. Nagan Raya.

Profil Puskesmas Alue Rampot tahun 2019

Wati.2016. Penyebab Meningkatnya Kejadian Dermatitis di lembaga permasyarakatan (Lapas) Kelas II B Kabupaten Kota . baru Kalimantan Selatan. Jurnal Formil..KesMas Respati, Volume 2, Nomor1,1, April 2016. ISSN 2550- 0864. Formil . kesmas.respati.ac.id

Zania, E, Junaid \& Ainurafiq.(2018). Faktor- faktor yang berhubungan dengan kejadian dermatitis pada nelayan di kelurahan induha kecamatan latambaga kabupaten kolaka tahun 2017. Jurnal Ilmiah Mahasiswa . Kesehatan Masyarakat 3(3)

Marniati, M., Putri, E. S., Mulyani, I., Khairunnas, K., Dharmayant, C. I., \& Nadiah, N. (2021). Feasibility Study of 3P Implementation in Handling Solid Waste by Empowering Housewives. J-Kesmas: Jurnal Fakultas Kesehatan Masyarakat (The Indonesian Journal of Public Health), 8(2), 23-28.

Melo, M. das G. M., Villarinho, A. L. C. F., \& Leite, I. da C. (2019). Sociodemographic and clinical profile of patients with occupational contact dermatitis seen at a work-related dermatology service, 2000 - 2014. Anais Brasileiros de Dermatologia, 94(2), 147156. https://doi.org/10.1590/abd1806-4841.20197235

Kraft, M., Schubert, S., Geier, J., Worm, M., Beiteke, U., Dissemond, J., ... Prager, W. (2019). Contact dermatitis and sensitization in professional musicians. Contact Dermatitis, 80(5), 273-278. https://doi.org/10.1111/cod.13191

Cros, P., Lodde, B., Roguedas-Contios, A.-M., Dewitte, J., \& Misery, L. (2016). Occupational Contact Dermatitis Caused By Seafood Proteins: Which Profession Is 
Most Affected? Journal of Allergy and Clinical Immunology, 137(2), AB153. https://doi.org/10.1016/j.jaci.2015.12.628

Wilke, A., Gediga, G., Goergens, A., Hansen, A., Hübner, A., John, S. M., ... Nashan, D. (2018). Interdisciplinary and multi-professional outpatient secondary individual prevention of work-related skin diseases in the metalworking industry: 1-year followup of a patient cohort. BMC Dermatology, 18(1). https://doi.org/10.1186/s12895$018-0080-2$

Marniati, M. (2017, November). Identifikasi Sosial Budaya Ibu Terhadap Pencegahan Diare Pada Balita. In Prosiding SEMDI-UNAYA (Seminar Nasional Multi Disiplin Ilmu UNAYA) (Vol. 1, No. 1, pp. 146-154).

Rinawati, S., \& Wulandari, S. M. (2020). The Related Of Personal Hygiene And Contact Frequency With Contact Dermatitis Complaints In Motorbike Washing Workers In Jebres And Mojosongo Surakarta Districts. Journal of Vocational Health Studies, 3(3), 109. https://doi.org/10.20473/jvhs.v3.i3.2020.109-113

Bahari, M. I. Y., \& Paramita, D. A. (2020). Correlation between Personal Hygiene, Household Hygiene, and Atopic Dermatitis in Elementary School Children in Indonesia. Majalah Kedokteran Bandung, 52(3), 144-148. https://doi.org/10.15395/mkb.v52n3.1971

Marniati, M. (2016, December). The Influence of People's Knowledge and Attitudes Toward Traditional Treatment. In 1st Public Health International Conference (PHICo 2016) (pp. 159-162). Atlantis Press.

Johansen, J. D., Aalto-Korte, K., Agner, T., Andersen, K. E., Bircher, A., Bruze, M., ... Uter, W. (2015). European Society of Contact Dermatitis guideline for diagnostic patch testing - Recommendations on best practice. Contact Dermatitis, 73(4), 195-221. https://doi.org/10.1111/cod.12432

Lopes, A., Sokolova, A., Abreu, C., \& Lopes, C. (2020, January 1). Atopic dermatitis host and environment model: Revisiting therapeutic options. European Annals of Allergy and Clinical Immunology. EDRA S.p.A. https://doi.org/10.23822/EurAnnACI.17641489.125

Stefanovic, N., Irvine, A. D., \& Flohr, C. (2021, September 1). The Role of the Environment and Exposome in Atopic Dermatitis. Current Treatment Options in Allergy. Springer Nature. https://doi.org/10.1007/s40521-021-00289-9

Tanacan, E., Aksoy Sarac, G., Emeksiz, M. A. C., Dincer Rota, D., \& Erdogan, F. G. (2020). Changing trends in dermatology practice during COVID-19 pandemic: A single tertiary center experience. Dermatologic Therapy, 33(6). https://doi.org/10.1111/dth.14136

Kutlu, Ö., Güneş, R., Coerdt, K., Metin, A., \& Khachemoune, A. (2020). The effect of the "stay-at-home" policy on requests for dermatology outpatient clinic visits after the COVID-19 outbreak. Dermatologic

Therapy, 33(4). https://doi.org/10.1111/dth.13581

de Lorenzo Alvarez, A., Revilla, Á., Corbalán, T., Villar, A., Espinel, L., Martins, J., \& Cubas, A. (2021). Ischemic stroke and purpuric dermatitis as COVID-19-related complications in a peritoneal dialysis patient. CEN Case Reports, 10(2), 250-254. https://doi.org/10.1007/s13730-020-00553-y

ahari, M. I. Y., \& Paramita, D. A. (2020). Correlation between Personal Hygiene, Household Hygiene, and Atopic Dermatitis in Elementary School Children in 


\section{ORFAI JOURNAL Multidiciplinary Output Research For

Indonesia. Majalah Kedokteran

https://doi.org/10.15395/mkb.v52n3.1971

Sodré, C. S., Rodrigues, P. M. G., Vieira, M. S., Marques Paes da Silva, A., Gonçalves, L. S., Ribeiro, M. G., \& Carvalho Ferreira, D. de. (2020, January 1). Oral mycobiome identification in atopic dermatitis, leukemia, and HIV patients-a systematic review. Journal of Oral Microbiology. Taylor and Francis Ltd. https://doi.org/10.1080/20002297.2020.1807179

Schmid-Grendelmeier, P., Takaoka, R., Ahogo, K. C., Belachew, W. A., Brown, S. J., Correia, J. C., ... Taïeb, A. (2019). Position Statement on Atopic Dermatitis in SubSaharan Africa: current status and roadmap. Journal of the European Academy of Dermatology and Venereology, 33(11), 2019-2028. https://doi.org/10.1111/jdv.15972

Rotaru, M., Matran, I. M., \& Iancu, G. M. (2020). Topical Maintenance Treatments in Chronic Dermatitis. Acta Medica Transilvanica, 25(3), 18-21. https://doi.org/10.2478/amtsb-2020-0042

Arora, C. J., Khattak, F. A., Yousafzai, M. T., Ibitoye, B. M., \& Shumack, S. (2020, July 1). The effectiveness of Janus kinase inhibitors in treating atopic dermatitis: A systematic review and meta-analysis. Dermatologic Therapy. Blackwell Publishing Inc. https://doi.org/10.1111/dth.13685

Kong, S., Koo, J., \& Lim, S. K. (2020). Associations between stress and physical activity in Korean adolescents with atopic dermatitis based on the 2018-2019 Korea youth risk behavior web-based survey. International Journal of Environmental Research and Public Health, 17(21), 1-8. https://doi.org/10.3390/ijerph17218175

Thyssen, J. P., Heegaard, S., Ivert, L., Remitz, A., Agner, T., DE BRUIN-WELLER, M., ... Bradley, M. (2020). Management of ocular manifestations of atopic dermatitis: A consensus meeting using a modified Delphi process. Acta DermatoVenereologica, 100(16), 1-6. https://doi.org/10.2340/00015555-3629

Simpson, E. L., Sinclair, R., Forman, S., Wollenberg, A., Aschoff, R., Cork, M., ... Rojo, R. (2020). Efficacy and safety of Abrocitinib. in adults and adolescents with moderateto-severe atopic dermatitis (JADE MONO-1): a multicentre, double-blind, randomized, placebo-controlled, phase 3 trial. The Lancet, 396(10246), 255-266. https://doi.org/10.1016/S0140-6736(20)30732-7

Fixsen, E., Patel, J., Selim, M. A., \& Kheterpal, M. (2019). Resolution of PembrolizumabAssociated Steroid-Refractory Lichenoid Dermatitis with Cyclosporine. The Oncologist, 24(3). https://doi.org/10.1634/theoncologist.2018-0531

Johansson, E. K., Ivert, L. U., Bradley, B., Lundqvist, M., \& Bradley, M. (2020). Weight gain in patients with severe atopic dermatitis treated with Dupilumab: A cohort study. BMC Dermatology, 20(1). https://doi.org/10.1186/s12895-020-00103-0

Dear, K., Palmer, A., \& Nixon, R. (2021). Contact allergy and allergic contact dermatitis from benzalkonium chloride in a tertiary dermatology center in Melbourne, Australia. Contact Dermatitis, 85(2), 146-153. https://doi.org/10.1111/cod.13826

McDowell, L., \& Olin, B. (2019, August 1). Crisaborole: A Novel Nonsteroidal Topical Treatment for Atopic Dermatitis. Journal of Pharmacy Technology. SAGE Publications Inc. https://doi.org/10.1177/8755122519844507

Reich, K., Kabashima, K., Peris, K., Silverberg, J. I., Eichenfield, L. F., Bieber, T., ... Simpson, E. L. (2020). Efficacy and safety of Baricitinib combined with topical corticosteroids for the treatment of moderate to severe atopic dermatitis: A 
randomized clinical trial. JAMA Dermatology, 156(12), 1333-1343. https://doi.org/10.1001/jamadermatol.2020.3260

M.J., L., \& D., P. (2020). Slime attack. British Journal of Dermatology, 182(1), E13. Retrieved from http://ovidsp.ovid.com/ovidweb.cgi?T=JS\&PAGE=reference \&D=emexb\&NEWS= $\mathrm{N} \& \mathrm{AN}=631581055$

Cam Van, T., \& Van Hieu, N. (2021). IDENTIFICATION OF MALASSEZIA SPECIES AND ITS ASSOCIATION WITH CLINICAL MANIFESTATIONS OF ATOPIC DERMATITIS. Tap $\quad C h i \quad Y \quad H o c \quad$ Việt Nam, 506(1-2). https://doi.org/10.51298/vmj.v506i1-2.992

Hedman-Lagerlöf, E., Fust, J., Axelsson, E., Bonnert, M., Lalouni, M., Molander, O., ... Bradley, M. (2021). Internet-Delivered Cognitive Behavior Therapy for Atopic Dermatitis: A Randomized Clinical Trial. JAMA Dermatology, 157(7), 796-804. https://doi.org/10.1001/jamadermatol.2021.1450

Zander, N., Sommer, R., Schäfer, I., Reinert, R., Kirsten, N., Zyriax, B. C., ... Augustin, M. (2019). Abstracts. The British Journal of Dermatology, 181(4), e92-e113. https://doi.org/10.1111/bjd.18388

Hernández-Fernández, C. P., Mercader-García, P., Silvestre Salvador, J. F., Sánchez Pérez, J., Fernández Redondo, V., Miquel Miquel, F. J., ... Borrego Hernando, L. (2021). Candidate Allergens for Inclusion in the Spanish Standard Series Based on Data from the Spanish Contact Dermatitis Registry. Actas Dermo-Sifiliograficas, 112(9), 798805.

https://doi.org/10.1016/j.ad.2021.05.005 